\title{
Gambaran Histologi dan Histomorfometri Limpa Kambing Peranakan Etawah
}

\section{(HISTOLOGICAL AND HISTOMORPHOMETRY DESCRIPTION OF ETAWAH CROSSBREED SPLEEN)}

\author{
Tri Ulfah Arema Yanti ${ }^{1 *}$, Ni Ketut Suwiti², Ni Luh Eka Setiasih ${ }^{2}$ \\ ${ }^{1}$ Praktisi Dokter Hewan di Kecamatan Wera, Kabupaten Bima, Nusa Tenggara Barat, \\ Indonesia 84152; \\ ${ }^{2}$ Laboratorium Histologi Veteriner Fakultas Kedokteran Hewan, Universitas Udayana, Jl. PB. \\ Sudirman Denpasar, Bali, Indonesia 80225. \\ *Email: ulfaharema@gmail.com
}

\begin{abstract}
ABSTRAK
Telah dilakukan penelitian tentang gambaran histologi dan histomorfometri limpa kambing peranakan etawah (PE). Sampel penelitian ini diambil dari limpa 10 ekor kambing PE jantan dan betina yang dipotong di tempat pemotongan hewan Kampung Jawa, Denpasar, Bali, selanjutnya difiksasi dalam larutan Neutral Buffer Formalin 10\% kemudian diproses untuk pembuatan preparat histologi berdasarkan metode Kiernan dengan teknik pewarnaan Hematoksilin-Eosin (HE). Limpa kambing PE tersusun atas kapsula, pulpa putih dan pulpa merah. Histomorfometri limpa kambing PE jantan dan betina diperoleh hasil masing-masing memiliki ketebalan kapsula 128,58 $\pm 0,37 \mu \mathrm{m}$ dan $163,40 \pm 0,35$ $\mu \mathrm{m}$, ketebalan trabekula $125,68 \pm 0,13 \mu \mathrm{m}$ dan $131,45 \pm 0,28 \mu \mathrm{m}$, dan diameter pulpa putih $466,63 \pm 0,15$ $\mu \mathrm{m}$ dan $392,40 \pm 0,30 \mu \mathrm{m}$. Disimpulkan bahwa jenis kelamin mempengaruhi struktur histologi dan histomorfometri limpa kambing peranakan eatawah (PE).
\end{abstract}

Kata kunci: Kambing peranakan Etawah (PE); histomorfometri; limpa.

\section{ABSTRACT}

The objective of this study to find out the histological and histomorphometry description of etawah crossbreed (PE) spleen. The spleens were collected from 10 male and female PE goats in Kampung Jawa slaughter house, Denpasar, Bali, then fixed in a solution of 10\% Neutral Buffer Formalin processed for making preparation histology based on the method of Kiernan with hematoxylin-Eosin (HE) staining techniques. The goat's spleen consists of capsule, white and red pulp. Spleen histomorphometry of male and female PE goats obtained results, each having a capsule thickness of $128.58 \pm 0.37 \mu \mathrm{m}$ and $163.40 \pm 0.35 \mu \mathrm{m}$, trabecula thickness of $125.68 \pm 0.13 \mu \mathrm{m}$ and $131.45 \pm 0,28$ $\mu \mathrm{m}$, and white pulp diameter $466.63 \pm 0.15 \mu \mathrm{m}$ and $392.40 \pm 0.30 \mu \mathrm{m}$ respectively. It was concluded that gender affected the histology structure and histomorphometry of etawah crossbreed spleen.

Keywords: Etawah Crossbreed; histomorphometry; spleen.

\section{PENDAHULUAN}

Kambing merupakan salah satu ternak yang sudah sangat dikenal oleh masyarakat, karena pemeliharaannya relatif mudah dan manfaatnya dapat dirasakan langsung oleh masyarakat. Manfaat kambing dapat dipandang dari segi finansial yakni dijual sebagai bibit ternak dan dipotong untuk dijual dagingnya maupun non-finansial untuk kepentingan upacara adat dan keagamaan. Salah satu jenis kambing yang banyak dipakai untuk keperluan tersebut di Indonesia khususnya di Bali adalah kambing peranakan etawah (Yupardhi et al., 2014).

Kambing peranakan etawah (PE) merupakan kambing hasil persilangan dari kambing lokal yaitu kambing kacang (Capra aegagrus hircus) dengan kambing etawah (asal india). Kambing PE merupakan kambing tipe dwiguna yaitu penghasil daging dan susu (Yupardhi et al., 
2013) serta memiliki produktivitas tinggi dan daya tahan tubuh yang baik. Selain itu, PE pejantan mempunyai seks-libido yang tinggi (Agung, 2010). Kambing PE tersebar hampir di seluruh Indonesia dan merupakan mayoritas dari seluruh populasi kambing di Bali (Guntoro et al., 2009), memiliki ciri khas bentuk muka cembung, dagu berjanggut, bergelambir, telinga panjang terkulai, ujung tanduk sedikit melengkung, tubuh tinggi dan ramping, garis punggung mengombak ke belakang, rambut panjang di bagian leher, pundak, punggung dan paha. memiliki tiga pola warna rambut, yaitu belang hitam, coklat, dan putih bertotol hitam (Pamungkas et al., 2008).

Terpenuhinya kondisi tubuh hewan yang sehat dan normal dapat memberikan jaminan produksi daging yang baik sehingga memberi ketenangan dan keamanan bagi masyarakat. Namun disisi lain, ketahanan tubuh hewan terhadap penyakit bervariasi, penyakit umumnya menimbulkan perubahan patologis dalam tubuh hewan sehingga pengetahuan mengenai kondisi normal dari organ yang berperan dalam sistem pertahanan tubuh perlu mendapat perhatian serius (Damayanti, 1996).

Untuk mencegah terjadinya infeksi patogen, tubuh dilengkapi oleh suatu sistem pertahanan yang diperankan oleh sistem limfatik. Salah satu organ pertahanan tubuh dalam hal ini adalah limpa. Limpa berperan penting dalam mengkoordinasi respon imun (Hidayati et al., 2018) serta berfungsi sebagai penyaring (filter) darah dan menyimpan zat besi untuk dimanfaatkan kembali dalam sintesis hemoglobin (Setiasih et al., 2011).

Histomorfometri adalah suatu metode pengukuran sel atau jaringan untuk mempelajari perubahan bentuk dan aktifitas dari sel melalui pengukuran volume, ketebalan, panjang, dan lebar suatu sel atau jaringan (Wahyuni et al., 2012). Sistem pertahanan dalam tubuh oleh limpa dapat dijadikan indikator status kesehatan kambing. Indikator tersebut dapat diamati dari gambaran histologi dan histomorfometrinya. Sampai saat ini belum ada laporan ilmiah tentang gambaran histologi dan histomorfometri limpa kambing peranakan etawah.

\section{METODE PENELITIAN}

\section{Sampel}

Penelitian ini bertujuan untuk mengetahui struktur histologi dan histomorfometri limpa kambing PE. Sampel penelitian ini diambil dari limpa 10 ekor kambing PE jantan dan betina yang dipotong di tempat pemotongan hewan Kampung Jawa, Denpasar, Bali. Limpa yang diambil adalah yang secara patologi anatomi tidak mengalami perubahan. Sampel dimasukkan ke dalam larutan Buffer Neutral Formalin 10\% selanjutnya diproses di dalam tissue processor untuk dibuat preparat. Preparat diwarnai dengan pewarnaan Haematoxylin-Eosin (HE) direndam dalam xylol I, II, dan III masingmasing selama 5 menit, selanjutnya direndam dalam alkohol absolut I dan II masing-masing selama 5 menit, selajutnya direndam dalam aquadest selama 1 menit, kemudian direndam dalam HarrisHematoksilin selama 15 menit, direndam dalam aquadest selama 1 menit dan 15 menit, selanjutnya direndam dalam eosin selama 2 menit, kemudian direndam dalam alkohol 96\% I, II, III dan IV masing-masing selama 3 menit, Preparat kemudian dibilas dengan xylol I dan II masing-masing selama 5 menit, dan diakhir pengerjaan dilakukan mounting yaitu penutupan preparat dengan cover glass yang menggunakan kanada balsam berisi entelan sebagai perekat, kemudian ditunggu hingga kering (Kiernan, 2001).

\section{Pengamatan Histologi}

Pengamatan struktur histologi limpa dilakukan pada lima lapang pandang pada carlzeiss teaching microscope dengan pembesaran lensa objektif 10x, 45x, dan 100x (Suwiti et al., 2015).

\section{Pengukuran histomorfometri}

Pengukuran histomorfometri limpa meliputi ketebalan kapsula, ketebalan trabekula, dan diameter pulpa putih 
dilakukan menggunakan carlzeiss teaching microscope dengan pembesaran lensa obyektif $5 \mathrm{x}$ dan 10x. Masing-masing dihitung pada setiap preparat lalu ukuran yang didapat kemudian dirata-ratakan dan dianalisis.

\section{Analisis Data}

Data hasil pengamatan struktur histologi limpa kambing PE dilaporkan secara deskriptif kualitatif, sedangkan data histomorfometri limpa kambing PE dilaporkan secara deskriptif kuantitatif dan uji Independent Sample T-Test pada SPSS.

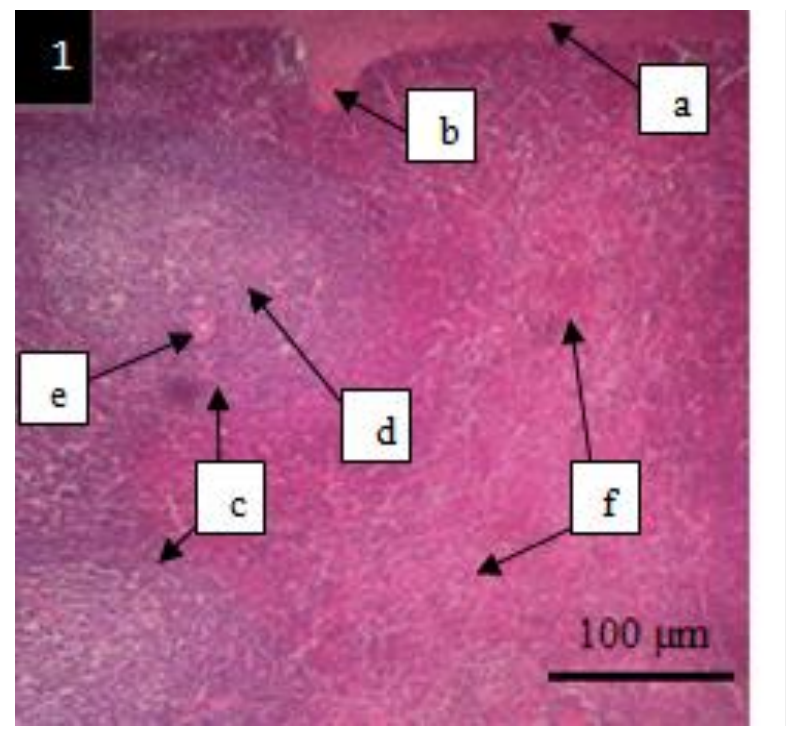

\section{HASIL DAN PEMBAHASAN}

\section{Struktur Histologi Limpa}

Limpa kambing PE tersusun atas kapsula, pulpa merah dan pulpa putih. Pulpa putih sebagian besar ditemukan di daerah perifer dengan jumlah yang lebih banyak ditemukan pada jantan (Gambar 1). Kapsula dan trabekula terdiri dari jaringan ikat dengan serabut kolagen dan elastis, fibroblas, sel mast, dan makrofag, pembuluh darah, serta otot polos (Gambar 2).

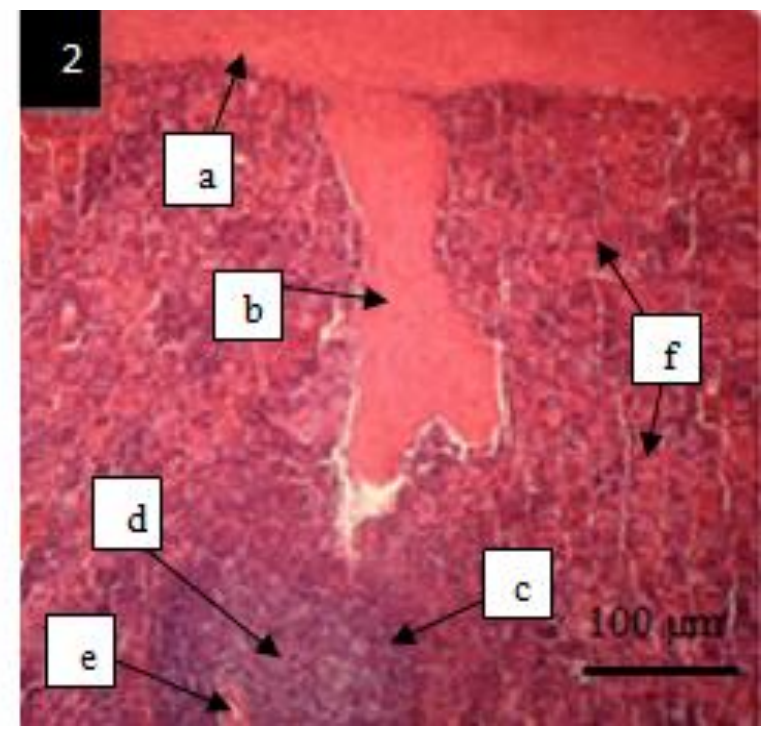

Gambar 1. Histologi Limpa Jantan (1) dan Betina (2) (HE. 100x). (a) Kapsula (b) Trabekula (c) Pulpa putih (d) Pusat Germinal (e) Arteri sentralis (f) Pulpa merah.

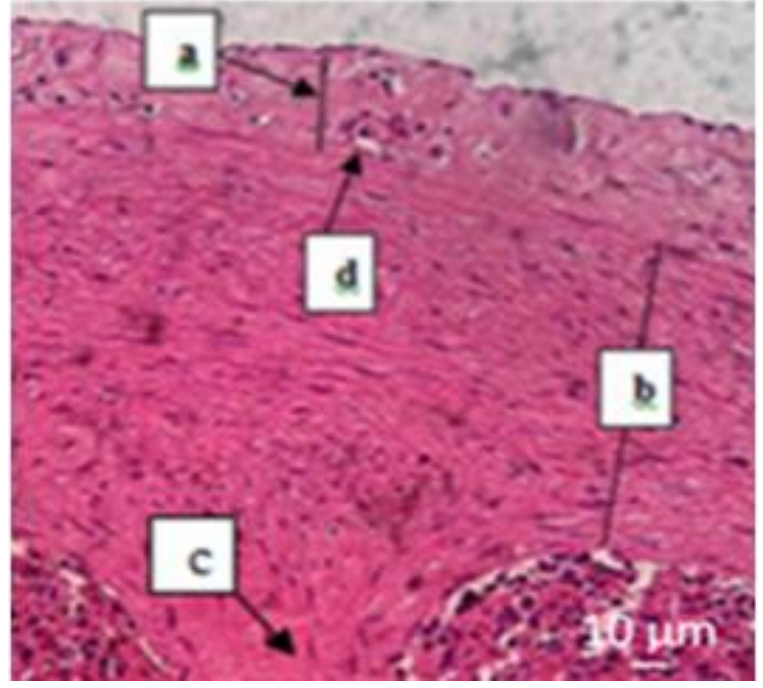

Gambar 2. Histologi Kapsula Limpa (HE. 1000x). (a) Jaringan ikat (b) Otot polos, serabut kolagen dan elastis (c) Trabekula (d) Pembuluh darah
Struktur histologi limpa kambing PE tersusun atas kapsula, pulpa putih dan pulpa merah. Temuan ini sesuai dengan hasil penelitian Setiasih et al. (2011). Kapsula dan trabekula terdiri dari jaringan ikat dengan serabut kolagen dan elastis, pembuluh darah dan otot polos. Komponen yang sama juga dilaporkan pada penelitian Khalel (2010) yakni pada kapsula limpa sapi memiliki 2-3 lapisan sel otot polos, kapsula limpa kuda memiliki jaringan ikat tebal dengan lapisan otot yang tipis dan halus kapsula limpa unta terdiri dari kapsula tebal terdiri dari jaringan ikat padat, serabut kolagen, elastis dan serat retikuler serta beberapa sel otot polos. Kemudian pada penelitian Onkar and Govardhan (2013), kapsula limpa anjing 
dan kucing relatif tipis dan terdiri dari otot polos dan serabut elastik.

Pulpa limpa terdiri dari pulpa putih dan pulpa merah. Pulpa putih tampak sebagai nodul limfatik dengan pusat germinal berwarna terang dan selubung periarterial limfatik (PALS) yang berisi arteri sentralis. Pulpa merah beraspek kemerahan terdiri dari sinus venosus, makrofag, sel plasma, dan limfosit (Gambar 3).
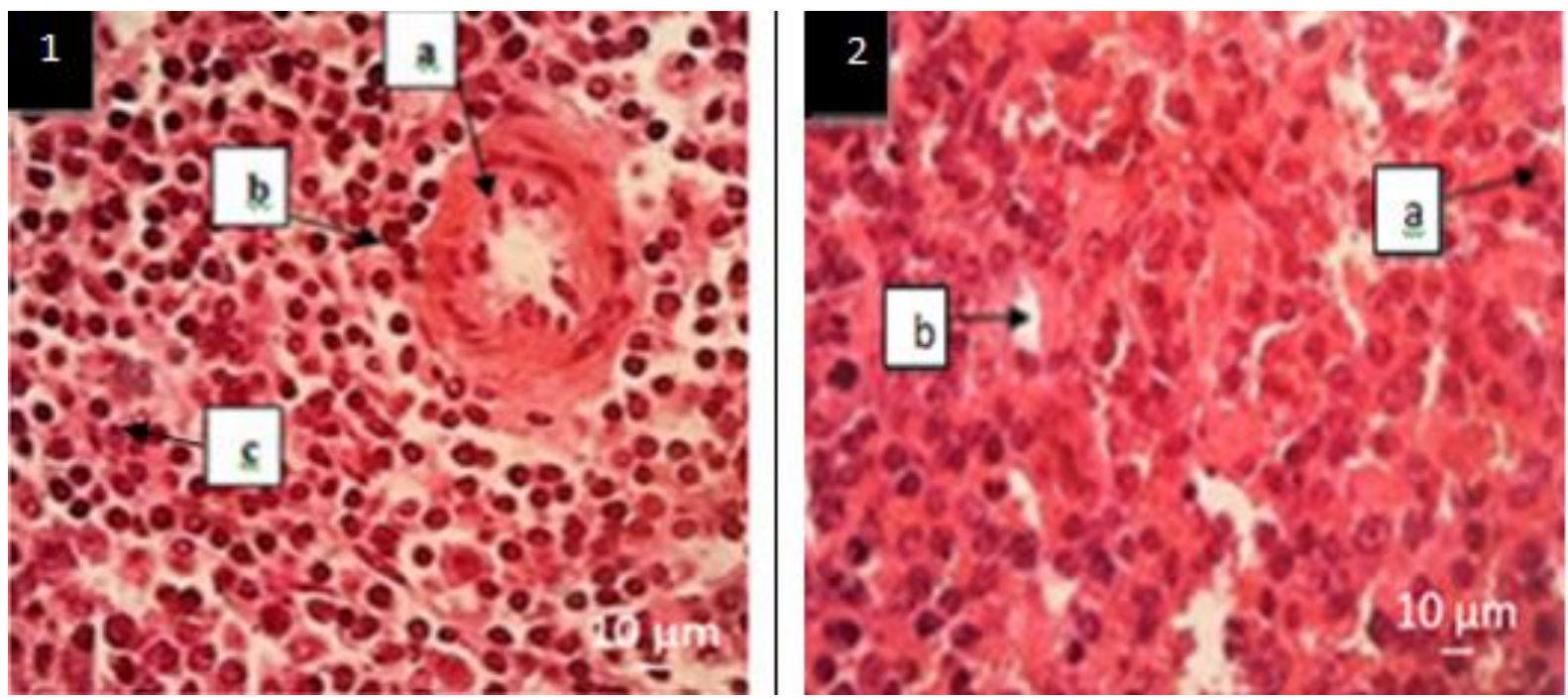

Gambar 3. Histologi Pulpa Putih (1) dan Pulpa Merah (2) Limpa (HE. 1000x). (1a) Arteri Sentralis (1b) PALS (1c) Sel retikuler dan serabut retikuler (2a) Limfosit (2b) Sinus Venosus.

Pulpa putih mengandung pusat germinal berwarna terang terdiri dari limfosit serta selubung periarterial limfatik atau PALS. Suatu penampang PALS berisi arteri sentralis. Menurut Cesta (2006), Arteri sentralis merupakan cabang dari arteri trabekularis yang letaknya eksentris dan melalui setiap nodulus limpa karena ketika meninggalkan trabekula, arteri sentralis diselubungi oleh jaringan limfatik, selubung tersebut meluas untuk membentuk nodulus limpa. Sel-sel utama dalam nodulus adalah limfosit $B$, sedangkan limfosit $\mathrm{T}$ menempati daerah yang langsung mengitari arteri nodularis. Hal ini sesuai dengan hasil penelitian Setiasih et al. (2011). Pulpa putih terdiri dari serabut retikuler dan sel retikuler membentuk jalinan stroma yang mengandung limfosit, makrofag, dan sel lainnya. Temuan yang sama juga dilaporkan pada penelitian Cesta (2006).
Pulpa merah limpa kambing PE terdiri dari sinus venosus dan cord. Sebagian besar pulpa limpa beraspek merah dan mengandung banyak darah karena pulpa merah merupakan filter darah yang mengeliminasi material asing dan berbahaya serta eritrosit yang sudah tua. Hal ini sesuai dengan hasil penelitian Setiasih et al. (2011) dan Krieken dan Orazi (2007). Sedangkan pada hasil penelitian Onkar and Govardhan (2013), selain cord dan sinus, pulpa merah anjing mengandung banyak ellipsoids (kapiler berdinding tebal) dan arteri penicillar. Zidan et al. (2000) juga melaporkan bahwa pada limpa unta, kuda, anjing dan babi memiliki sinus venosus melimpah dan dikatakan jenis sinusal. Perbedaan struktur histologi limpa kambing PE jantan dan betina disajikan pada Tabel 1, sementara hasil pengukuran histomorfometri limpa kambing peranakan etawah disajikan dalam Tabel 2. 
Tabel 1. Struktur Histologi Limpa Kambing PE Jantan dan Betina

\begin{tabular}{|c|c|c|c|}
\hline \multirow{2}{*}{$\begin{array}{l}\text { Struktur } \\
\text { Histologi }\end{array}$} & \multirow{2}{*}{$\begin{array}{c}\text { Komponen } \\
\text { Penyusun }\end{array}$} & \multicolumn{2}{|c|}{ Jenis Kelamin } \\
\hline & & Jantan & Betina \\
\hline $\begin{array}{c}\text { Kapsula dan } \\
\text { trabekula }\end{array}$ & $\begin{array}{l}\text {-Jaringan ikat } \\
\text {-Serabut kolagen } \\
\text { dan elastis } \\
\text {-Pembuluh darah } \\
\text {-Otot polos } \\
\text {-Fibroblast } \\
\text {-Sel mast } \\
\text {-Makrofag }\end{array}$ & $\begin{array}{l}\text { Kapsula tipis } \\
\text { dengan trabekula } \\
\text { yang tipis dan } \\
\text { pendek }\end{array}$ & $\begin{array}{l}\text { Kapsula tebal dengan } \\
\text { trabekula yang lebih } \\
\text { tebal dan panjang }\end{array}$ \\
\hline Pulpa Putih & $\begin{array}{l}\text {-PALS } \\
\text {-Arteri sentralis } \\
\text {-Pusat Germinal } \\
\text {-Serabut dan sel } \\
\text { retikuler (limfosit, } \\
\text { makrofag) }\end{array}$ & $\begin{array}{l}\text { Lebih banyak di } \\
\text { daerah perifer } \\
\text { dengan pusat } \\
\text { germinal yang } \\
\text { berwarna terang } \\
\text { dan jumlah yang } \\
\text { lebih banyak dari } \\
\text { betina }\end{array}$ & $\begin{array}{l}\text { Lebih banyak di } \\
\text { daerah perifer dengan } \\
\text { pusat germinal yang } \\
\text { berwarna terang }\end{array}$ \\
\hline Pulpa Merah & $\begin{array}{l}\text {-Sinus venosus } \\
\text {-Makrofag } \\
\text {-Sel plasma } \\
\text {-Limfosit }\end{array}$ & - & - \\
\hline
\end{tabular}

Tabel 2. Hasil Pengukuran Histomorfometri Limpa Kambing PE.

\begin{tabular}{lcc}
\hline \multirow{2}{*}{ Histomorfometri } & \multicolumn{2}{c}{ Jenis Kelamin } \\
\cline { 2 - 3 } & $\begin{array}{c}\text { Jantan } \\
(\text { Rata-rata } \pm \text { SD) }\end{array}$ & $\begin{array}{c}\text { Betina } \\
(\text { Rata-rata } \pm S D)\end{array}$ \\
\hline Ketebalan Kapsula $(\mu \mathrm{m})$ & $128,58 \pm 0,37^{\mathrm{a}}$ & $163,40 \pm 0,35^{\mathrm{b}}$ \\
Ketebalan Trabekula $(\mu \mathrm{m})$ & $125,68 \pm 0,13^{\mathrm{a}}$ & $131,45 \pm 0,28^{\mathrm{b}}$ \\
Diameter Pulpa Putih $(\mu \mathrm{m})$ & $466,63 \pm 0,15^{\mathrm{a}}$ & $392,40 \pm 0,30^{\mathrm{b}}$ \\
\hline
\end{tabular}

Keterangan: Huruf yang berbeda pada baris yang sama menunjukkan perbedaan nyata $(\mathrm{P}<0,05)$.

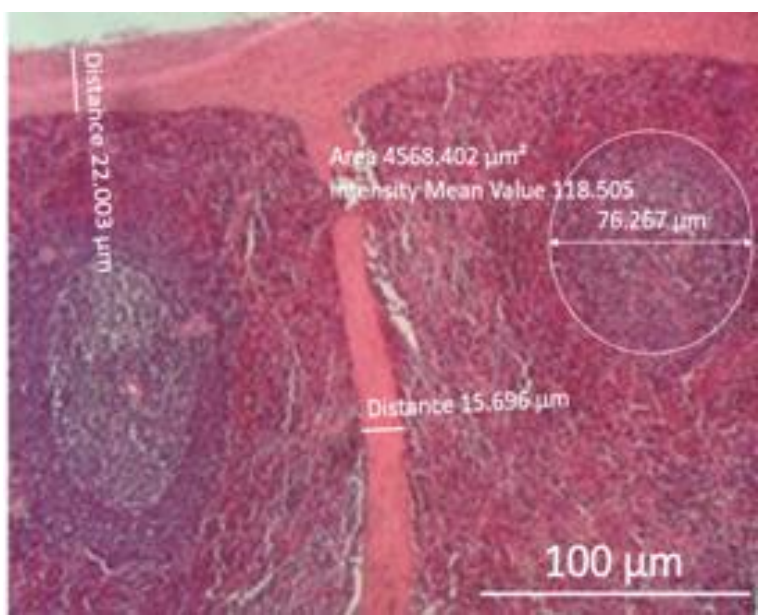

Gambar 4. Histomorfometri limpa (HE. 100x)
Kapsula dan trabekula yang ditemukan pada limpa betina lebih tebal dibandingkan jantan. Hal ini dipengaruhi oleh ketebalan jaringan ikat penyusun kapsula ditentukan oleh banyaknya kandungan serabut kolagen. Temuan ini didukung oleh Dewi et al. (2016), yang menyatakan bahwa kadar kolagen ditentukan oleh jenis kelamin, umur dan kadar lemak. Kapsula dan trabekula merupakan komponen yang sangat penting untuk menimbulkan kontraksi yang kuat ketika tubuh membutuhkan darah dan berperan penting dalam kekebalan tubuh (Khalel, 2010). 
Kambing jantan memiliki jumlah pulpa putih yang lebih banyak dengan diameter yang lebih luas dibandingkan yang betina. Hal ini erat kaitannya dengan sel-sel utama pada pulpa putih adalah leukosit terutama limfosit yang berhubungan erat dengan sistem pertahanan tubuh hewan, sehingga jumlahnya yang lebih banyak pada jantan akan mempengaruhi jumlah dan diameter pulpa putih.

Pada umumnya jumlah leukosit pada hewan jantan dan betina berbeda. Menurut Yanto et al. (2015), perbedaan tersebut selain dipengaruhi oleh kondisi patologis, faktor penting yang berpengaruh adalah jenis kelamin, umur, serta pertumbuhan dan perkembangan. Jenis kelamin merupakan faktor penting karena erat hubungannya dengan aktifitas fisiologi dari ternak tersebut dan ada kecendurungan dengan bertambahnya umur, jumlah leukosit semakin menurun dan pada jantan lebih tinggi dibanding dengan betina. Hal ini didukung oleh Laksmindra dan Mulyati (2014), yang menyatakan bahwa jumlah limfosit atau leukosit hewan jantan lebih tinggi karena massa tubuh atau berat badan hewan jantan lebih tinggi daripada betina, hal ini dipengaruhi oleh ekspresi androgen (testosteron) yang berperan dalam mengendalikan pertumbuhan.

Limpa kambing PE tergolong tipe pertengahan/intermedier yaitu memiliki kapsula dan trabekula seimbang serta pulpa merah dan pulpa putih seimbang. Hal ini sesuai dengan yang dilaporkan oleh Zidan et al. (2000) bahwa selain limpa babi, limpa ruminansia juga merupakan tipe pertengahan /intermedier. Sedang tipe limpa yang lain ditemukan pada limpa kelinci dengan kapsula relatif tipis, trabekula dan otot polos sedikit, pulpa putih lebih banyak dari pulpa merah sehingga merupakan tipe pertahanan /defensif. Kemudian pada hasil penelitian Onkar and Govardhan (2013) menemukan bahwa limpa anjing, kuda dan kucing merupakan tipe penyimpan dengan kapsula dan trabekula tebal, kaya otot polos dan serabut elastis serta pulpa merah lebih banyak dari pulpa putih.

\section{SIMPULAN DAN SARAN}

\section{Simpulan}

Limpa kambing peranakan etawah (PE) tersusun atas kapsula, pulpa putih dan pulpa merah. Kambing betina memiliki kapsula yang lebih tebal dengan trabekula yang tebal dan panjang dibandingkan yang jantan. Pulpa putih ditemukan lebih banyak di daerah perifer dengan jumlah yang lebih banyak pada jantan serta diameter yang lebih luas dibandingkan pada betina.

\section{Saran}

Perlu dilakukan penelitian tentang gambaran histologi dan histomorfometri limpa kambing peranakan etawah yang diamati berdasarkan variasi umur.

\section{UCAPAN TERIMAKASIH}

Penulis mengucapkan terimakasih kepada kepala Laboratorium Histologi Veteriner Fakultas Kedokteran Hewan Universitas Udayana, serta semua pihak yang telah membantu dalam proses penelitian ini.

\section{DAFTAR PUSTAKA}

Agung P. 2010. Budidaya Ternak Kambing. Balai Pengkajian Teknologi Pertanian Sumatera Selatan.

Cesta MF. 2006. Normal structure, function, and histology of the spleen. Toxicol. Pathol. 34: 455-465.

Damayanti R. 1996. Deteksi fenotipik subset limfosit $t$ pada limfoglandula sapi bali yang terserang penyakit ingusan dengan teknik imunohistokimiawi. J. Ilmu Ternak Vet. 2(2): 120-126.

Dewi AM, Swacita IBN, Suwiti NK. 2016. Pengaruh perbedaan jenis otot dan lama penyimpanan terhadap nilai nutrisi daging sapi bali. Bul. Vet.Udayana. 8(2): 135-144.

Goh YM. 2008. Experimental Design and Sampel Size Issues in Laboratory Animal Experiments. Departemen of Veterinary Preclinical Sciences, 
Faculty of Veterinary Medicine. University Putra Malaysia.

Guntoro S, Arimbawa IB, Jemmy R. 2009. Pengkajian perbibitan plasma nutfah kambing gembrong untuk meningkatkan populasi dan keragaman. Laporan Hasil Penelitian. Denpasar. Balai Pengkajian Teknologi Pertanian Bali.

Hidayati E, Berata IK, Samsuri, Merdana IM, Sudimartini LM. 2018. Gambaran histopatologi limpa tikus putih yang diberi deksametason dan vitamin E. Bul. Vet. Udayana. 10(1): 18-25.

Khalel EM. 2010. Anatomical and histological study of the spleen in iraqi sheep (Awasi sheep). Bas. J. Vet. Res. 10(2): 163-171.

Kiernan J. 2001. Histological and Histocemical Methods. $3^{\text {rd }}$ Ed. Toronto. Arnold Pub. Pp. 330-354.

Krieken JHJM, Orazi A. 2007. Spleen. In: Histopathology for Pathologist. Ed ke3. Philadelphia (US): Williams \& Wilkins.

Laksmindra F, Mulyati S. 2014. Profil hematologi tikus (Rattus norvegicus Berkenhout, 1769) Galur Wistar jantan dan betina umur 4, 6, dan 8 minggu. $J$. Ilmiah Biol. 2(2): 94-100.

Onkar DP, Govardhan SA. 2013. Comparative histology of human and dog spleen. J. Morphol. Sci. 30(1): 1620.

Pamungkas FA, Batubara A, Doloksaribu M, Sihite E. 2008. Petunjuk Teknis Potensi Beberapa Plasma Nutfah Kambing Lokal Indonesia. Pusat
Penelitian dan Pengembangan Peternakan. ISBN: 978-602-8475-04-4. Setiasih NLE, Suwiti NK, Suastika P, Piraksa IW, Susari NNW. 2011. Studi histologi limpa sapi bali. Bul. Vet. Udayana. 3(1): 2085-2495

Suwiti NK, Suastika IP, Swacita IBN, Besung INK. 2015. Studi Histologi dan Histomorfometri Daging Sapi Bali dan Wagyu. J. Vet. 16(3): 432-438.

Wahyuni S, Agungpriyono S, Agil M, Yusuf TL. 2012. Histologi dan histomorfometri testis dan epididimis muncak (Muntiacus muntjak muntjac) pada periode rangga keras. J. Vet. 13(3): 211-219.

Yanto H, Hasan H, Sunarto. 2015. Studi hematologi untuk diagnosa penyakit ikan secara dini di sentra produksi budidaya ikan air tawar Sungai Kapuas Kota Pontianak. J. Akuatika. 6(1): 1120.

Yupardhi WS, Oka IGL, Mantra IB. 2013. Hematologi dan kimia klinik darah kambing peranakan etawah yang diberi pakan limbah pertanian disuplementasi dengan enzim optizym. J. Vet. 14(1): 99-104.

Yupardhi WS, Oka IGL, Mantra IB, Suyasa IN, Suranjaya IG. 2014. Gambaran darah kambing gembrong, kambing peranakan etawah, dan kambing kacang di Bali. J. Vet. 15(4): 494-498.

Zidan M, Kassem A, Dougbag A, Ghazzawi E, Aziz MAE, Pabst R. 2000. The spleen of the one humped camel (Camelus dromedarius) has a unique histological structure. J. Anat. 196: 425-432. 